\title{
Double Burden of Malnutrition among Undergraduates in Ogun State Nigeria
}

\author{
Oladoyinbo Catherine $\mathrm{A}^{1}$, Ekerette Nkere $\mathrm{N}^{2}$ \\ ${ }^{1}$ Department of Nutrition and Dietetics, Federal University of Agriculture, Abeokuta, Ogun State, Nigeria \\ ${ }^{2}$ Department of Human Ecology, Nutrition and Dietetics, University of Uyo Akwa-Ibom Nigeria
}

\section{Article Info \\ Article history: \\ Received Jul 22, 2015 \\ Revised Sep 20, 2015 \\ Accepted Oct 06, 2015}

\section{Keyword:}

Abdominal fat

Double burden

Obesity

Undergraduates

Underweight

\begin{abstract}
Coexistence of under and over nutrition among the same population group is referred to as the double burden of malnutrition. The objective of this study was to assess double burden of malnutrition among undergraduate students in Ogun State Nigeria. A cross-sectional study involving 1,115 (37.8\%) males and $1,835(62.2 \%)$ females was conducted. Body mass index (BMI) was derived from weight and a height measurement, waist circumference (WC) measurement was taken to assess abdominal obesity. SPSS version 16 was used for data analysis. Mean age, height, weight and BMI were $23 \pm 0.05$ years, $\quad 1.63 \pm 0.001 \mathrm{~m}, \quad 60.99 \pm 0.22 \mathrm{~kg} \quad$ and $\quad 22.80 \pm 0.08 \mathrm{kgm}^{-2}$ respectively. Mean WC was $82.21 \pm 0.32 \mathrm{~cm}$ and $80.55 \pm 0.49 \mathrm{~cm}$ among males and females respectively. Based on BMI, the Prevalence of underweight, overweight and obesity were $13.4 \%, 16.9 \%$ and $7.5 \%$ respectively. BMI did not relate significantly with both age $(\mathrm{p}=0.464)$ and gender $(\mathrm{P}=0.115)$. About fifty percent $(50.64 \%)$ of females and $12.36 \%$ males who were overweight and obese also had excess abdominal fat. Prevalence of abdominal obesity was significantly higher among females $(16.9 \%)$ than males $(2.5 \%),(\mathrm{p}=0.001)$. Respondents in this study were faced with problems of both under-nutrition and over-nutrition.
\end{abstract}

Copyright ( 2015 Institute of Advanced Engineering and Science. All rights reserved.

\section{Corresponding Author:}

Oladoyindo Catherine A,

Department of Nutrition and Dietetics,

Federal University of Agriculture,

Abeokuta, Ogun State, Nigeria.

Email: cathbadejo@yahoo.com

\section{INTRODUCTION}

The double burden of malnutrition is referred to as the co-existence of under- and over-nutrition occurring simultaneously within a population [1]. Both obesity and underweight have been associated with the incidence of various diseases [2]. Under-nutrition and obesity are both among the top ten leading risk factor for the global burden of disease [2]. Overweight and obesity occur as a result of energy imbalance i.e. when caloric intake exceeds energy expenditure [3],[4]. This leads to excessive accumulation of fat in the adipose tissue of the body and this is associated with and predisposes to the development of Non Communicable Diseases (CVD) such as Type 2 diabetes, coronary heart disease, atherosclerosis, hypercholesterolemia, stroke, hypertension, different types of cancers, asthma, other respiratory diseases, increased morbidity and mortality [2]-[3],[5]-[9].

On the other hand, under-nutrition is usually an outcome of inadequate dietary intake and or diseases [10]. It lowers the body's ability to resist infection which leads to longer, more severe and more frequent illness [10],[11]. It has been described as the underlying cause of child's death associated with diarrhoea, pneumonia, malaria and measles [12]. Increasingly all developing countries of the world including Nigeria have both under-nutrition and over-nutrition problems i.e. the double burden of malnutrition [11]. 
Obesity hitherto seen predominantly in developed countries has now become a potential health problem in the developing countries where under-nutrition has been a problem despite the prevailing socio economic situation [13]. Africa, a continent usually synonymous with hunger, is falling prey to obesity [14]. The transition to the double burden of malnutrition in the developing countries of the world has been linked to unplanned urbanization, industrialization, globalization and economic development with exposure to and consumption of high fat and refined foods, tobacco, alcohol consumption and physical inactivity [3]-[6], [7][9].

The co-existence of under-nutrition (underweight) and over-nutrition (overweight and obesity) and their attendant implications make the double burden phenomenon particularly important. In developing countries, comprehensive data on prevalence of obesity is scanty and it is thought that obesity is a disease of affluent societies only [3]. In Nigeria there are few data to support the prevalence of both conditions among members of the entire population. Therefore this study aims at finding the prevalence of underweight, overweight and obesity among undergraduates in Ogun State Nigeria.

\section{RESEARCH METHOD Study Design}

A cross-sectional descriptive study of 2950 apparently healthy male and female (non-pregnant) undergraduates (male and female) of Tai Solarin University of Education Ijagun Ijebu-Ode Ogun state was carried out. Using a simple random technique, ten (10) departments out of the four (4) colleges in the institution were randomly selected. The students were also randomly selected from these departments. Informed consent of the participants was obtained and ages of the respondents were also obtained.

\subsection{Anthropometric measurements}

Weight in $\mathrm{kg}$ was measured using an electronic weighing scale while height in meters was measured using a stadiometer. Body Mass Index $(\mathrm{BMI})$ was calculated $\left[\mathrm{BMI}=\right.$ weight $\left.(\mathrm{kg}) / \mathrm{height}^{2}\left(\mathrm{~m}^{2}\right)\right]$ and was used to define underweight $\left(\mathrm{BMI}<18.5 \mathrm{~kg} / \mathrm{m}^{2}\right)$, normal weight $(\mathrm{BMI}=18.5$ to 24.99$)$, overweight $(\mathrm{BMI}=25$ to 29.99$)$, obesity type I (BMI $=30$ to 34.99$)$, obesity type II $(\mathrm{BMI}=35$ to 39.99$)$ and morbid obesity $(\mathrm{BMI}>$ 40).

Waist circumference (WC) was measured using a measuring tape. Abdominal obesity was defined as a $\mathrm{WC} \geq 102 \mathrm{~cm}$ and $\geq 88 \mathrm{~cm}$ for men and women, respectively (WHO, 2004). The risk of CVD and type 2 diabetes is increased in men and women with abdominal adiposity.

\subsection{Data analysis}

Statistical analysis was carried out using Statistical Package for Social Science (SPSS) version 15. Descriptive statistics of mean and standard deviations were used to examine the age and gender specific anthropometric indices. Chi-square and correlations were also done. P-value $<0.05$ was considered to be statistically significant.

\section{RESULTS AND ANALYSIS}

A total of 2950 undergraduate students participated in the study which comprised $1115(37.8 \%)$ male and $1835(62.2 \%)$ female students of the Tai Solarin University of Education Ijagun Ijebu-Ode in Ogun state. Table 1 shows the mean age, weight, height, BMI and waist circumference of the students. The mean age, height and weight of the students were $23 \pm 0.05 y$ ears, $1.63 \pm 0.001 \mathrm{~m}$ and $60.99 \pm 0.22 \mathrm{~kg}$ respectively. The mean BMI was $22.80 \pm 0.08 \mathrm{kgm}^{-2}$ and waist circumference among males and females were $82.21 \pm 0.32 \mathrm{~cm}$ and $80.55 \pm 0.49 \mathrm{~cm}$ respectively. In Table 2 , from the total number of respondents, $13.4 \%$ were underweight, $62.1 \%$ had normal weight, $16.9 \%$ were over-weight while $7.5 \%$ were obese out of which $0.6 \%$ were morbidly obese. Although not statistically significant there were higher rates of underweight, overweight and obesity among the female students. There was no significant difference in the body mass index category among the male and female undergraduates $(\mathrm{p}=0.464)$.

Table 3 shows that the prevalence of obesity as determined according to the waist circumference classification was $11.5 \%$. The prevalence was $16.9 \%$ among female and $2.5 \%$ among the male students. There was a significant difference in the prevalence of obesity as measured by the accumulation of excess abdominal fat among male and female students $(\mathrm{p}=0.001)$. 
Table 1. Mean age, height, weight, waist circumference and BMI

\begin{tabular}{cccccc}
\hline Gender & Age (Years) & Height $(\mathrm{m})$ & Weight $(\mathrm{kg})$ & Waist $(\mathrm{cm})$ & $\begin{array}{c}\text { Body mass circumference } \\
\text { index }\left(\mathrm{kgm}^{-2}\right)\end{array}$ \\
\hline Male & 23.16 & 1.65 & 62.10 & 82.21 & 22.77 \\
Mean & 0.088 & 0.002 & 0.368 & 0.316 & 0.139 \\
SE & 1115 & 1115 & 1115 & 1115 & 115 \\
N & & & & & 22.80 \\
Female & 23.24 & 1.63 & 60.30 & 80.55 & 0.106 \\
Mean & 0.070 & 0.002 & 0.279 & 0.486 & 1835 \\
SE & 1835 & 1835 & 1835 & 1835 & 22.80 \\
N & & & & & 0.084 \\
Total & 23.25 & 1.63 & 60.99 & 81.17 & 2950 \\
Mean & 0.549 & 0.002 & 0.223 & 0.325 & 2950 \\
SE & 2950 & 2950 & 2950 & & \\
N & & &
\end{tabular}

Table 2. Body mass index category by gender

\begin{tabular}{|c|c|c|c|c|}
\hline Body mass Index & $\begin{array}{c}\text { Male } \\
\text { N (\%) }\end{array}$ & $\begin{array}{c}\text { Female } \\
\mathrm{N}(\%)\end{array}$ & $\begin{array}{c}\text { Total } \\
\text { N (\%) }\end{array}$ & $\mathrm{P}$ \\
\hline Under-weight & $154(5.2)$ & $242(8.2)$ & $396(13.4)$ & \multirow{6}{*}{0.464} \\
\hline Normal weight & $702(23.8)$ & $1131(38.3)$ & $1833(62.1)$ & \\
\hline Overweight & $178(6.0)$ & $322(10.9)$ & $500(16.9)$ & \\
\hline Obesity Type I & $57(1.9)$ & $107(3.6)$ & $164(5.6)$ & \\
\hline Obesity Type II & $15(0.5)$ & $23(0.8)$ & $38(1.3)$ & \\
\hline Morbid obesity & $9(0.3)$ & $10(0.3)$ & $19(0.6)$ & \\
\hline
\end{tabular}

Table 3. Abdominal obesity by gender

\begin{tabular}{ccccc}
\hline \multirow{2}{*}{ Gender } & Normal & Excess abdominal fat & Total & \multirow{2}{*}{$\mathrm{P}$} \\
\cline { 2 - 4 } & $\mathrm{N}(\%)$ & $\mathrm{N}(\%)$ & $\mathrm{N}(\%)$ & \\
\hline Female & $1524(83.1)$ & $310(16.9)$ & $1835(100)$ & 0.001 \\
Male & $1087(97.5)$ & $28(2.5)$ & $115(100)$ & \\
Total & $2611(88.5)$ & $338(11.5)$ & $2949(100)$ & \\
\hline
\end{tabular}

There was no significant relationship between age of the students and BMI $(\mathrm{P}=0.101)$. Also there was no significant relationship between age and waist circumference $(P=0.484)$. However, there was a significant relationship between BMI and waist circumference as shown in Table 4.

About half (50.64\%) of the overweight and obese students also had excess abdominal fat among the female students whereas, $12.36 \%$ of overweight and obese males had abdominal obesity. Out of the 10 morbidly obese, $8(80 \%)$ had excess abdominal fat among the female students while out of the 242 underweight, only $2(0.008 \%)$ had excess abdominal fat. Out of the 154 underweight students none had excess abdominal fat while out of the 9 who had morbid obesity, $8(88 \%)$ had excess abdominal fat.

Table 4. Body mass index category by waist circumference category

\begin{tabular}{|c|c|c|c|c|c|c|c|c|}
\hline \multirow[t]{2}{*}{ Gender } & $\begin{array}{c}\text { Under } \\
\text { Weight }\end{array}$ & $\begin{array}{c}\text { Normal } \\
\text { weight }\end{array}$ & $\begin{array}{c}\text { Over } \\
\text { weight }\end{array}$ & $\begin{array}{l}\text { Obesity } \\
\text { Type I }\end{array}$ & $\begin{array}{l}\text { Obesity } \\
\text { Type II }\end{array}$ & $\begin{array}{l}\text { Morbid } \\
\text { obesity }\end{array}$ & Total & \multirow[t]{2}{*}{$\mathrm{P}$} \\
\hline & $\mathrm{N}(\%)$ & $\mathrm{N}(\%)$ & $\mathrm{N}(\%)$ & $\mathrm{N}(\%)$ & $\mathrm{N}(\%)$ & $\mathrm{N}(\%)$ & $\mathrm{N}(\%)$ & \\
\hline \multicolumn{9}{|l|}{ Female } \\
\hline Normal & $240(13.1)$ & $1056(57.5)$ & $183(10)$ & 34 (1.9) & $9(0.5)$ & $2(0.1)$ & $1524(83)$ & \multirow{3}{*}{0.001} \\
\hline Excess Abdominal fat & $2(0.1)$ & $75(4.1)$ & $139(7.6)$ & $73(4.0)$ & $14(0.8)$ & $8(0.4)$ & $311(17)$ & \\
\hline Total & $242(13.2)$ & $1131(61.6)$ & $322(17.6)$ & $107(5.8)$ & $23(13.0)$ & $10(0.5)$ & $1834(100)$ & \\
\hline \multicolumn{9}{|l|}{ Male } \\
\hline Normal & $154(13.8)$ & $695(62.3)$ & $173(15.5)$ & $43(3.9)$ & $10(0.9)$ & $1(0.1)$ & $1076(96.5)$ & \multirow{3}{*}{0.004} \\
\hline Excess Abdominal fat & $0(0)$ & $7(0.6)$ & $5(0.4)$ & $14(1.3)$ & $5(0.4)$ & $8(0.7)$ & $39(3.5)$ & \\
\hline Total & $154(13.8)$ & $702(63.0)$ & $178(16.0)$ & $57(5.1)$ & $15(1.3)$ & $9(0.8)$ & $1115(100)$ & \\
\hline
\end{tabular}

\subsection{Discussions}

The main aim of this study was to provide data that support the occurrence of both under-nutrition and over-nutrition among undergraduate students in Ogun State Nigeria. The respondents in this study were mostly young adults as indicated by the mean age obtained. The mean height, weight and BMI from this study are comparable with the results of Adu et al [15] where the mean height, weight and BMI were $1.63 \pm 0.23 \mathrm{~m}, 64.00 \pm 9.09 \mathrm{~kg}$ and $24.53 \pm 3.34 \mathrm{kgm}^{-2}$. The values for the mean waist circumference (WC) 
obtained from this study was similar to the values obtained by Amole et al., [9] where the mean WC amongst males was $84.1 \pm 12.7 \mathrm{~cm}, 90.4 \pm 14.6 \mathrm{~cm}$ amongst female and $87.6 \pm 14.1 \mathrm{~cm}$ over the entire group of adults in Ogbomosho Nigeria.

Adu et al., [15] reported 15\% for underweight among undergraduate students in South-West Nigeria. The same study however reported a prevalence of $53 \%$ overweight and $6 \%$ obesity among the same population and this is similar to the results obtained in this study. In a study carried out among adult population in Northern Nigeria, $31.6 \%$ of the population were either overweight or obese and $6.6 \%$ underweight [2].

The coexistence of both under-nutrition and over-nutrition among respondents in this study is obvious. The World Health Organization reported that while under-nutrition and infectious diseases continue to pose serious health challenges in low-income countries, overweight and obesity assume important and major risk factors for cardiovascular diseases in the same settings; constituting the fifth leading risk for global deaths [16]. Over-nutrition which has been regarded as an alien phenomenon [17] in many developing countries like Nigeria has risen to the point of becoming a public health issue while undernutrition still poses a typical challenge.

It has been reported that composition of diets and dietary habits among Nigerians have changed towards increased frequency of food consumption, canteen or restaurant eating, snacking as well as lower intakes of fruits and vegetables [18]. This of course could explain the high rate of overweight and obesity observed among participants in the study. Comparatively, while it is easier to correct under-nutrition by simple measures, overweight and obesity result from complex mechanisms involving both biological and environmental factors which makes it difficult to manage and reverse the condition [19]. Tackling the problem of overweight and obesity at this younger age will prevent it from tracking into older age where it could compound health challenges associated with ageing.

Although the difference was not statistically significant, more girls were affected by both underweight and overweight than the males. It is important to take into consideration that, females constituted about three quarters of the study participants, a factor that could take advantage of the sample size in observing both under and over-nutrition. Findings in gender differences in the prevalence of overweight and obesity is consistent across most findings. Reports have shown that the female gender is an as important predictor of overweight and obesity among individuals [13],[20]-[21]. The reason for this may not be farfetched as body composition is affected by several factors including gender; the female gender associated with greater storage of body fat [22].

Waist circumference, a marker of visceral obesity, has been implicated in predicting several chronic conditions including diabetes mellitus [23], high blood pressure [24], heart diseases [25] and other cardiovascular diseases [5]. High waist circumference i.e. a waist circumference of $\geq 102 \mathrm{~cm}$ for men and $\geq$ $88 \mathrm{~cm}$ for women has been implicated as a risk factor for CVD and diabetes [5]. Perez-Cueto et al [26] in a study among 15-19 year old Jamaicans revealed that high waist circumference was $10 \%$ and this results is similar to the findings of this study. Amole et al. [9] also showed that the prevalence of high waist circumference was $33.8 \%$ among adults in Ogbomosho.

Several factors have been identified to predispose to abdominal adiposity. These include physical inactivity, consumption of fast food and sweetened beverages, urbanization and greater socio economic status [27]-[28]. These factors may contribute to the high prevalence of overweight and obesity observed in this study. Although the factors contributing to the high prevalence of abdominal obesity was not assessed in this study, low intake of fruits and vegetables, high consumption of sweetened drinks, snacking, breakfast skipping are characteristic of young adults who are the respondents in this study.

There was a significant relationship between body mass index and waist circumference $(\mathrm{P}=0.001)$ among the females. About half of the female students $(50.64 \%)$ who were overweight and obese also had excess abdominal fat while $0.008 \%$ of the students who were underweight had excess abdominal fat. Among the male undergraduates, $12.5 \%$ of the overweight and obese also had excess abdominal fat $(\mathrm{P}=0.004)$. Based on proven evidence, cardio-metabolic risk may be better controlled when therapeutic measures are taken from patients' BMI in combination with their waist circumference (http://www.myhealthywaist.org/fileadmin/pdf/3\%20Abdominal\%20Obesity.pdf).

\section{CONCLUSION}

Both under-nutrition and over-nutrition are existing among the respondents in this study. Underweight, Overweight and obesity are public health problems especially among the female undergraduates. Female students seem to have a higher prevalence of obesity than their male counterparts. Nutrition education as a means of intervention is urgently needed to curb the increasing trend of overweight and obesity in Nigeria where the problem of under-nutrition has been a nightmare. 


\section{REFERENCES}

[1] Kennedy G., Nantel G., Shetty P., "Assessment of the double burden of malnutrition in six case study countries", Food and Agriculture Organization food and Nutrition, 2006. ftp://ftp.fao.org/docrep/fao/009/a0442e/a0442e00.pdf

[2] Bakari AG., Onyemelukwe GC., Sani BG., et al., "Obesity, overweight and underweight in suburban Northern Nigeria”, J Diabetes Metab, vol. 15, pp. 68-9, 2007.

[3] Akpa MR., Mato CN., "Obesity in Nigeria: current trends and management", Nigeria Medical Practitioner, vol. 54, pp. 11-5, 2008. www.ajol.info/index.php/nmp/article/view/28941.

[4] Ogunjimi LO., Ikorok MM., Yusuf OO., "Prevalence of obesity among Nigerian nurses: the Akwa-Ibom state experience", Int. NGOJ, vol. 5, pp. 45-9, 2009.

[5] Thiam I., Samba K., Lwanga D., "Diet related chronic disease in the West African region", In: Diet related chronic disease and double burden of malnutrition in West Africa, SCN, 2006.

[6] Akinpelu AO., Oyewole OO., Oritogun KS., "Overweight and obesity: does it occur in Nigerian adolescents in an urban community?", Int Journal of Biomedical and Health Sciences, vol. 4, pp. 11-7, 2008.

[7] Ojofeitimi EO., Olugbenga-Bello EA., Adekanle DA., "Pattern and determinants of obesity among adolescent females in private and public schools in the Olorunda Local Government Area of Osun State, Nigeria: a comparative study", Journal of Public Health in Africa, vol. 2, pp. 45-9, 2011.

[8] Ramon A., Luke A., Cooper RS., et al., "Rapid increases in obesity in Jamaica compared to Nigeria and the United States", BMC Public Health, vol. 8, pp. 133, 2008.

[9] Amole IO., OlaOlorun AD., Odeigha LO., Adesina SA., "The prevalence of abdominal obesity and hypertension among adults in Ogbomosho Nigeria", African J. of Primary Health care \& Family Medicine, pp. 112-8, 2011.

[10] Standing Committee on Nutrition, "Nutrition for Improved development Actions", $5^{\text {th }}$ Report on the World Nutrition Situation. 2004. www.unsystem.org/scn/Publications/AnnualMeeting/.../

[11] Shripton R., "Life cycle gender perspectives on the double burden of malnutrition and prevention of diet related chronic diseases", In: Diet related chronic disease and double burden of malnutrition in West Africa, SCN, 2006.

[12] Caulfield LE., Mercedes de Onis, Blossner M., Black ER., "Under nutrition as an underlying cause of child's deaths associated with diarrhoea, pneumonia, malaria, and measles", Am J Clin Nutr, vol. 80, pp. 193-8, 2006.

[13] Ansa VO., Odigwe CO., Anah, MU., "Profile of body mass index and obesity in Nigerian children and adolescents", Niger J of Medicine, vol/issue: 10(2), pp. 78-80, 2001.

[14] Jackson MD., Djafarian K., Stewart J., Speakman JR., "Increased television viewing is associated with elevated body fatness but not with lower total energy expenditure in children", Am J Clin Nutr, vol. 89, pp. 1031-6, 2009.

[15] Adu OB., Falade AM., Nwalutu EJ., et al., "Nutritional status of undergraduates in a Nigerian university in South West Nigeria", Int. J. Med. Med. Sci., vol/issue: 1(8), pp. 318-24, 2009.

[16] World Health Organization, "Obesity and overweight" [webpage on the Internet] Geneva, Switzerland: World Health Organization, 2011. Available from: http://www.who.int/mediacentre/factsheets/fs $311 / \mathrm{en} / \mathrm{print} . \mathrm{html}$.

[17] Wang Y., Chen HJ., Shaikh S., Mathur P., "Is obesity becoming a public health problem in India? Examine the shift from under- to over-nutrition problems over time", Obes Rev, vol. 10, pp. 456-74, 2009.

[18] Abidoye RO., Izunwa RD., Akinkuade FO., Abidoye GO., "Inter-relationships between lifestyle and diabetes mellitus, overweight/obesity and hypertension in Nigeria", Nutr Health, vol. 16, pp. 203-13, 2002.

[19] Wyatt HR., "Update on Treatment Strategies for Obesity", J Clin Endocrinol Metab, vol. 98, pp. 1299-306, 2013.

[20] Bader Z., Musaiger AO., Al-Roomi K., D’Souza R., "Overweight and obesity among adolescents in Bahrain", Anthropol Anz, vol. 66, pp. 401-7, 2008.

[21] Malik M., Bakir A., "Prevalence of overweight and obesity among children in the United Arab Emirates", Obes Rev, vol. 8, pp. 15-50, 2007.

[22] Smolin, Grosvenor, "Nutrition Science and Application. $2^{\text {nd }}$ edition", John Wiley \& Sons, Inc., pp. 321, 2010.

[23] Ekpenyong CE., Akpan UP., Nyebuk ED., John O. Ibu, "Detecting incident type 2 diabetes mellitus in South Eastern Nigeria: The role of adiposity indices in relation to gender", J. Diabetes Endocrinol., vol. 2, pp. 62-7, 2011.

[24] Olufemi Sola Adediran, Philip Babatunde Adebayo, Adeseye Abiodun Akintunde, "Anthropometric differences among natives of Abuja living in urban and rural communities: correlations with other cardiovascular risk factors", BMC Research Notes, vol. 6, pp. 1-23, 2013.

[25] Yusuf S., Hawken S., Ounpuu S., et al., "Obesity and the risk of myocardial infarction in 27000 participants from 52 countries: a case control study", Lancet, vol. 366, pp. 1640-9, 2005.

[26] Perez-Cueto FJ., Botti AB., Verbeke W., "Prevalence of overweight in Bolivia: data on women and adolescents", Obes Rev, vol. 10, pp. 373-77, 2009.

[27] Francis DK., Van den Broeck J., Younger N., et al., "Fast-Food and sweetened beverage consumption: association with overweight and high waist circumference in adolescents", Public Health Nutr, vol/issue: 12(8), pp. 1106-14, 2009.

[28] Ansa O., Anah MU., Ndifon WO., "Soft drinks consumption and overweight and obesity among Nigerian adolescents", CVD Prevention and Control, vol/issue: 3(4), pp. 191-6, 2008. 